\title{
PENGARUH VARIASI ARUS PADA PENGELASAN GMAW TERHADAP KEKUATAN DAN KEKERASAN BAJA ST 60
}

\author{
Abdul Lutdfi Pratama*, Slamet Supriyadi, Hisyam Ma'mun \\ Jurusan Teknik Mesin, Universitas PGRI Semarang Jl. Sidodadi Timur No. 24 \\ Kota Semarang, 50232 \\ *Email: lutdfipratama@gmail.com
}

\begin{abstract}
Abstrak
Berkembangnya dunia industri yang semakin maju tidak dapat dipisahkan dengan proses pengelasan. Pengelasan merupakan teknik menyambung dua logam atau lebih dengan memanfaatkan energi panas untuk mencairkan logam induk. Dalam pengelasan banyak faktor yang mempengaruhi salah satunya adalah kuat arus pengelasan. Studi kekuatan dan kekerasan pada sambungan las telah ditentukan pada plat baja ST60 tebal $6 \mathrm{~mm}$ dengan menggunakan pengelasan GMAW dan menggunakan arus 90, 100, dan 110 Ampere dan tujuan studi ini menguji kekuatan tarik dan kekerasan pada sambungan las. Dari arus 95, 100, dan 110 Ampere diperoleh Rata-rata hasil uji 333,2 HV, 464,1 HV, dan 558, 1 HV. Nilai kekerasan rata-rata tertinggi ialah pada arus 110 Ampere. Kemudian pada pengujian tarik, nilai uji tarik pada arus 90, 100, dan 110 Ampere diperoleh rata-rata hasil uji 418,3 MPa, 545,5 MPa, dan 633,3 MPa. Nilai kekuatan tarik tertinggi ialah pada arus 110 A. Dari hasil yang diperoleh dapat disimpulkan bahwa semakin tinggi arus pengelasan yang dipakai, maka semakin tinggi nilai kekerasan dan kekuatan tarik baja ST 60.
\end{abstract}

Kata Kunci : Baja ST60, GMAW, kekerasan dan uji tarik

\section{PENDAHULUAN}

Pengelasan GMAW (gas metal arc welding) adalah pengelasan yang menggunakan shielding gas. Shielding gas berfungsi sebagai pelindung logam las saat proses pengelasan berlangsung agar tidak terkontaminasi dari udara lingkungan sekitar logam lasan. Karena logam lasan sangat rentan terhadap difusi hidrogen yang dapat menyebabkan cacat porosity. Pengelasan GMAW dapat menggunakan gas argon (Ar) yang biasa disebut MIG (Metal Inert Gas) ataupun gas karbondioksida $\left(\mathrm{CO}_{2}\right)$ (Purkuncoro, 2019).

Baja ST60 merupakan salah satu baja yang mudah terserang korosi, baja yang salah satunya digunakan sebagai bahan baku pembuat pipa ini tergolong baja karbon sedang. Baja ST60 juga dapat digunakan atau dapat diaplikasikan dengan mudah untuk kegiatan manufaktur, contohnya adalah pengelasan (Yudi dkk., 2019).

Salah satu bahan yang memiliki sifat mampu las yang baik adalah baja karbon. Baja karbon memiliki spesifikasi yang bervariasi, namun yang sering mengalami keretakan pada hasil pengelasan adalah baja karbon sedang dan baja karbon tinggi karena sifat bahan yang keras dan kuat. Pengelasan yang menggunakan teknik las yang sama kuat dengan logam lasnya akan mudah mengalami patahan. Pada umumnya konstruksi bangunan yang dilakukan dengan proses pengelasan sering mengalami kerusakan saat menerima pembebanan seperti patahan, melentur, cacat atau kerusakan yang tidak diinginkan pada daerah bagian sambungan las. Identifikasi dalam penelitian ini adalah pengaruh variasi arus pengelasan pada baja ST60 dengan menggunakan pengelasan GMAW. Tujuan dari penelitian ini adalah sebagai berikut mengetahui pengaruh variasi arus terhadap kekerasan dan kekuatan pada sambungan pengelasan.

Pengelasan adalah salah salah satu teknik penyambungan logam dengan cara mencairkan sebagian logam induk dan logam pengisi dengan atau tanpa tekanan dan dengan atau tanpa logam penambah dan menghasilkan sambungan yang kontinyu. Pengelasan juga dapat diartikan sebagai ikatan tetap dari benda atau logam yang dipanaskan (Yudi dkk., 2019).

Las GMAW merupakan proses pengelasan busur listrik, dengan busur listrik diselimuti oleh gas di atas daerah pengelasan. Kawat las pengisi yang juga berfungsi sebagai elektroda diumpankan secara terus-menerus. 
Gas pelindung yang digunakan adalah Argon, Helium atau campuran dari keduanya (Wijoyo \& Aji, 2015).

\section{METODOLOGI}

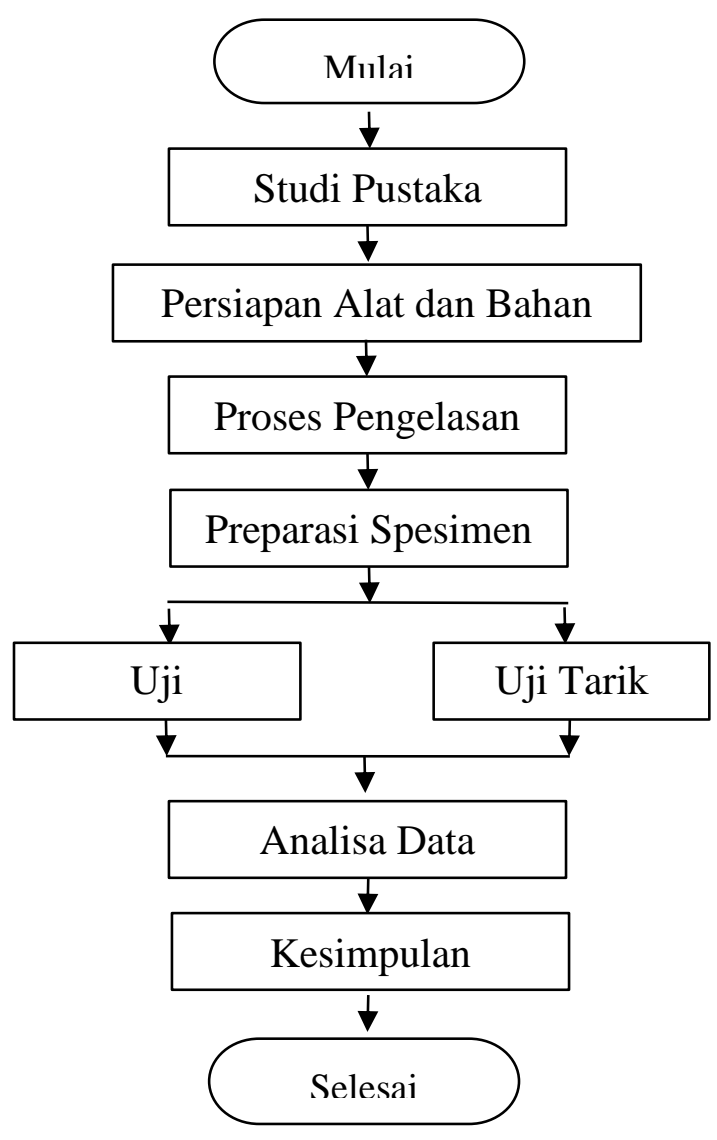

Gambar 1. Desain Penelitian

Penelitian ini menggunakan material baja ST60 yang termasuk baja karbon sedang. Kandungan karbon dalam material ini sebesar $0.60 \%$. pengelasan GMAW digunakan dengan menggunakan arus 90, 100, dan 110 Ampere. Setelah proses pengelasan dilanjutkan dengan proses pengujian kekuatan dan kekerasan pada spesimen uji. Pengujian tarik dilakukan di laboratorium Material Teknik Universitas Wahid Hasyim Semarang.

Selain melakukan uji tarik, dalam penelitian ini juga dilakukan uji kekerasan. Lokasi pembuatan spesimen pengujian dan proses pengujian kekerasan dengan metode Vickers dilakukan di Laboratorium Teknik Mesin Universitas PGRI Semarang. Uji kekerasan Vickers menggunakan identor yang berbentuk Pyramid intan yang dasarnya berbentuk bujur sangkar dengan sudut $136^{\circ}$. Angka kekerasan Vickers (Vickers hardness number) didefinisikan sebagai beban dibagi dengan luas permukaan lekukan (Haryadi, 2006).

Besar sudut antara permukaan yang terdapat pada piramida intan ini memiliki sudut $136^{\circ}$ dan memiliki dua tipe pembebanan yang digunakan pada metode ini yaitu mikro 10-1000 g dan makro 1-100 Kg. Tujuan dari pengujian kekerasan suatu material dengan bentuk daya tahan material terhadap yang dibebankan. Pengujian kekerasan dengan metode Vickers, bertujuan menentukan kekerasan suatu material dalam yaitu daya tahan material terhadap indentor intan yang cukup kecil dan mempunyai bentuk geometri berbentuk piramida.

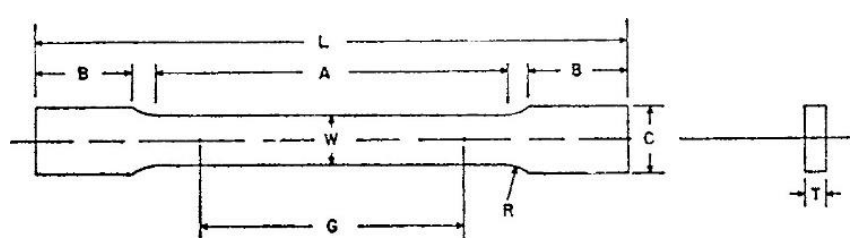

Gambar 2. Acuan standar spesimen (ASTM E8, 2010)

Tabel 1. Keterangan dimensi ASTM E38

\begin{tabular}{|c|c|c|c|}
\hline \multirow[t]{2}{*}{ Dimensions } & $\begin{array}{c}\text { Plate-Type, } \\
40 \mathrm{~mm} \\
\text { [1.500 In.] } \\
\text { Wide }\end{array}$ & $\begin{array}{c}\text { Sheet-Type, } \\
12.5 \mathrm{~mm} \\
\text { [0.500 In.] } \\
\text { Wide }\end{array}$ & $\begin{array}{c}6 \mathrm{~mm} \\
\text { [0.250 In.] } \\
\text { Wide }\end{array}$ \\
\hline & $\mathrm{mm}$ [in.] & mm [in.] & $\mathrm{mm}$ [in.] \\
\hline \multirow[t]{2}{*}{$G$-Gauge length } & $200.0 \pm 0.2$ & $50.0 \pm 0.1$ & $25.0 \pm 0.1$ \\
\hline & {$[8.00 \pm 0.01]$} & $\begin{array}{c}{[2.000 \pm} \\
0.005]\end{array}$ & $\begin{array}{c}{[1.000 \pm} \\
0.003]\end{array}$ \\
\hline \multirow[t]{2}{*}{ W-Width } & $40.0 \pm 2.0$ & $12.5 \pm 0.2$ & $6.0 \pm 0.1$ \\
\hline & $\begin{array}{c}{[1.500 \pm} \\
0.125,- \\
0.250]\end{array}$ & $\begin{array}{c}{[0.500 \pm} \\
0.010]\end{array}$ & $\begin{array}{c}{[0.250 \pm} \\
0.005]\end{array}$ \\
\hline T-Thickness & & $\begin{array}{c}\text { thickness of } \\
\text { material }\end{array}$ & \\
\hline $\begin{array}{l}R-\text { Radius of } \\
\text { fillet, } \text { min }\end{array}$ & $25[1]$ & $12.5[0.500]$ & $6[0.250]$ \\
\hline $\begin{array}{l}L-\text { Overall length, } \\
\min \end{array}$ & $450[18]$ & $200[8]$ & $100[4]$ \\
\hline $\begin{array}{l}A-\text { Length of } \\
\text { reduced section, } \\
\text { min }\end{array}$ & 225 [9] & 57 [2.25] & 32 [1.25] \\
\hline $\begin{array}{l}B \text { - Length of grip } \\
\text { section, min }\end{array}$ & $75[3]$ & $50[2]$ & $30[1.25]$ \\
\hline $\begin{array}{l}\text { C-Width of grip } \\
\text { section, } \\
\text { approximate }\end{array}$ & $50[2]$ & $20[0.750]$ & $10[0.375]$ \\
\hline
\end{tabular}

\section{HASIL DAN PEMBAHASAN \\ Pengujian Tarik}

Pada penelitian ini spesimen yang digunakan untuk pengujian berjumlah 9 
spesimen. Standar ukuran pengujian menggunakan standart ASTM E8M. Setelah spesimen melalui proses pengelasan kemudian spesimen Preparasi sesuai standar yang digunakan kemudian dilakukan pengujian tarik.

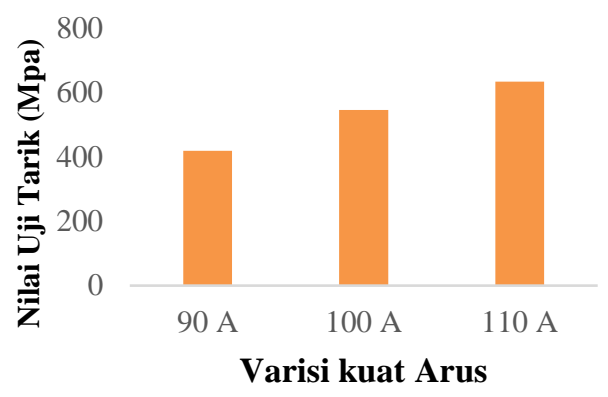

Gambar 3. Grafik Nilai Uji Tarik

Berdasarkan data hasil pengujian tarik seperti gambar 3 terlihat pada material hasil pengelasan, nilai kekuatan tarik meningkat seiring bertambah arus Ampere. Hasil pengujian tarik yang diperoleh memiliki nilai paling rendah pada arus 90 Ampere yaitu sebesar 418.3 MPa, pada arus 100 Ampere memiliki nilai sebesar 545.5 $\mathrm{MPa}$, dan pengujian tarik yang diperoleh memiliki nilai paling tinggi pada arus $110 \mathrm{~A}$ yaitu sebesar 633.3 MPa. Pengujian ini menujukan bahwa bertambahnya arus Ampere pada pengelasan GMAW menunjukkan bahwa semakin besar arus yang di gunakan maka akan bertambahnya nilai pengujian tarik sedangkan pada pengujian tarik.

\section{Hasil Pengujian Kekerasan}

Pada penelitian ini menggunakan alat uji kekerasan dengan metode Vickers yang sering disebut dengan nilai kekerasan HV (hardness Vickers), pada alat uji ini indentor yang digunakan berupa intan berbentuk kerucut atau yang sering disebut dengan diamond pyramid hardness Test (DPH) dengan sudut sebesar $136^{\circ}$. Pengujian dilakukan pada 9 sampel yang telah melalui proses pengelasan dengan variasi arus pengelasan. Prinsip pada proses pengujian kekerasan Vickers yaitu dengan cara menekankan indentor yang berupa piramida intan pada permukaan spesimen yang akan diuji, kedalaman penekanan akan memberikan nilai kekerasan dengan perbedaan kedalaman penekanan yang diperoleh dari pembebanan. pada setiap sampel dilakukan indentasi sebanyak 3 kali Pengujian. Dari pengujian tersebut diperoleh data nilai kekerasan sebagai berikut:

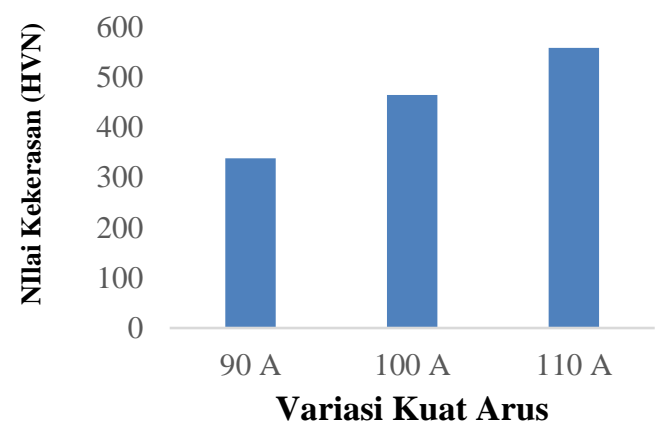

\section{Gambar 4. Grafik nilai kekerasan}

Berdasarkan Gambar 4 data hasil pengujian kekerasan dan kekuatan material, hasil pengelasan cenderung meningkat di setiap penambahan arusnya pada arus $90 \mathrm{~A}$ diperoleh nilai kekerasan rata-rata $333.2 \mathrm{HV}$, pada arus 100 A diperoleh hasil kekerasan rata-rata 464.1 $\mathrm{HV}$, pada arus $110 \mathrm{~A}$ diperoleh hasil rata-rata nilai kekerasan 558.1 HV. Hasil penelitian ini menunjukkan bahwa pengelasan GMAW pada baja ST60 bahwa semakin besar Ampere yang di gunakan, maka kekerasan material semakin besar pula.

\section{PENUTUP \\ Kesimpulan}

Berdasarkan penelitian yang telah penulis lakukan mengenai pengaruh variasi arus terhadap kekuatan dan kekerasan hasil lasan baja ST60, dapat ditarik kesimpulan sebagai berikut:

Hasil pengujian tarik yang dilakukan menunjukkan bahwa, semakin besar arus Ampere yang di gunakan maka semakin tinggi nilai ketangguhannya. Hasil pengujian tarik yang telah dilakukan pada material hasil pengelasan diperoleh nilai kekuatan tarik tertinggi pada pengelasan arus $110 \mathrm{~A}$ dengan nilai rata-rata kekuatan tarik sebesar $633.3 \mathrm{MPa}$. Arus 110 A merupakan variasi arus pengelasan tertinggi sedangkan pada arus $90 \mathrm{~A}$ di peroleh hasil nilai rata-rata sebesar $481.3 \mathrm{MPa}$.

1. Hasil pengujian kekerasan yang dilakukan menunjukkan bahwa, semakin 
besar arus Ampere yang di gunakan maka semakin tinggi nilai kekerasan. Hasil pengujian kekerasan yang telah dilakukan pada material diperoleh nilai kekerasan rata-rata paling tinggi didapat pada pengelasan arus $110 \mathrm{~A}$ dengan nilai kekerasan rata-rata sebesar 558.1 HV. Arus 110 A merupakan variasi arus

2. pengelasan tertinggi sedangkan pada arus 90 A diperoleh hasil rata - rata sebesar $333.2 \mathrm{HV}$.

\section{Saran}

Dalam penelitian ini dapat dirangkum beberapa saran yang berkaitan dengan penelitian ini adalah sebagai berikut:

1. Pada proses pengelasan harus diperhatikan benar-benar penyetingan pada arus Ampere, pemilihan besar arus pengelasan yang digunakan akan berpengaruh terhadap kekuatan tarik dan kekerasan.

2. Pada saat selesai melakukan pengelasan, jangan menggunakan media air untuk proses pendinginan maka dapat mengakibatkan deformasi akibat panas yang berlebih.

\section{DAFTAR PUSTAKA}

ASTM E8. (2010). ASTM E8/E8M standard test methods for tension testing of metallic materials 1. Annual Book of ASTM Standards 4, C, 1-27. https://doi.org/10.1520/E0008

Haryadi, G. D. (2006). Pengaruh suhu tempering terhadap kekerasan, kekuatan tarik dan struktur mikro pada baja K-460. ROTASI. https://ejournal.undip.ac.id/index.php/r otasi/article/download/2386/2111

Purkuncoro, A. E. (2019). ANALISIS PENGARUH VARIASI ARUS LISTRIK 90 A, 10 A, 130 A TERHADAP SIFATMEKANIS DAN STRUKTURMIKROHASIL

PENGELASAN GASMETAL

Industri Inovatif: Jurnal Teknik Industri.

https://ejournal.itn.ac.id/index.php/ind ustri/article/download/372/358
Wijoyo, W., \& Aji, B. K. (2015). Kajian Kekerasan dan Struktur Mikro Sambungan Las GMAW Baja Karbon Tinggi dengan Variasi Masukan Arus Listrik. Simetris: Jurnal Teknik Mesin, Elektro dan Ilmu .... https://jurnal.umk.ac.id/index.php/simet/ar ticle/view/459

Yudi, G. A., Respati, S. M. B., \& Syafa'at, I. (2019). ANALISIS LAJU KOROSI BAJA ST 60 PASCA PROSES LAS GTAW DENGAN VARIASI ARUS LAS 80, 100, 120 A DAN DIRENDAM PADA LARUTAN HCL BERSUHU $\ldots$. MAJALAH ILMIAH $\ldots$. https://www.ojs2.unwahas.ac.id/index.php /MOMENTUM/article/view/2660 